\title{
STUDY OF ANTARCTIC-SOUTH AMERICA CONNECTIVITY FROM IONOSPHERIC RADIO SOUNDINGS
}

\section{Emília Correia}

Instituto Nacional de Pesquisas Espaciais (INPE). São José dos Campos, SP, Brazil.

Centro de Rádio Astronomia Astrofísica Mackenzie (CRAAM). Escola de Engenharia. Universidade Presbiteriana Mackenzie. Rua da Consolação 930, Ed. Modesto Carvalhosa $6^{\circ}$ andar, 603. CEP: 01302-907. São Paulo, SP, Brazil.

E-mail: ecorreia@craam.mackenzie.br

\begin{abstract}
Multi-instrument probing of the ionosphere at high latitudes is of great interest to improve our understanding of it, and because the processes originated in the interplanetary space print your signatures there. Nowadays, the ionosphere has been probed by many different radio techniques, from geodetic observations (GPS), passing by radar measurements up to the analysis of very low frequency (VLF) wave paths. The simultaneous and integrated observations have been provided the ability to study the ionosphere from the F-region to bottom of the D-layer, and also the coupling processes from the magnetosphere to the neutral atmosphere. The study of the Antarctic-South America connectivity is important to understand/characterize how the polar atmospheric variations can affect the lower latitudes, in which context, the instrument networks are essential. This paper presents the radio techniques that have been used at Comandante Ferraz Brazilian Station in Antarctica and over the South America territory for probing the ionosphere, as well the instrumentation characteristics and in which network it is integrated. It also provides some recent scientific results obtained from the ionospheric soundings.
\end{abstract}

Keywords: Ionosphere; radio soundings; Antarctic; South America.

\section{RESUMO}

ESTUDO DA CONECTIVIDADE ANTÁRTICA-AMÉRICA DO SUL A PARTIR DE RÁDIO SONDAGENS DA IONOSFERA. Sondagens da ionosfera feitas com múltiplos instrumentos, nas altas latitudes, são de grande interesse para ampliar nosso conhecimento sobre essa região, e porque lá os processos que se originam no espaço interplanetário deixam suas marcas. Atualmente a ionosfera tem sido monitorada por diferentes técnicas na faixa rádio, indo das observações de GPS, passando por medidas de radares até a análise de propagação de ondas de frequência muito baixa (VLF). As observações simultâneas e integradas tem permitido estudar a ionosfera desde o topo da região $\mathrm{F}$ até a base da região $\mathrm{D}$, e também os processos de acoplamento desde a magnetosfera até a atmosfera neutra. O estudo da conectividade entre Antártica e América do Sul é importante para se entender/caracterizar como as variações atmosféricas que estão acontecendo nas regiões polares afetam as latitudes mais baixas, e em cujo contexto, as redes de instrumentos são essenciais. Este artigo apresenta as técnicas de rádio sondagens em uso na Estação Antártica Comandante Ferraz e na América do Sul para se estudar a ionosfera, bem como as características da instrumentação utilizada e em quais redes elas estão integradas. Apresentamos também alguns resultados de pesquisa recentemente obtidos destas sondagens.

Palavras-chave: Ionosfera; sondagens rádio; Antártica; América do Sul.

\section{RESUMEN}

ESTUDIO DE LA CONECTIVIDAD ANTÁRTIDA-SUDAMÉRICA A PARTIR DE RADIO SONDEOS DE LA IONÓSFERA. Sondeos multi-instrumento de la ionósfera, realizados a altas latitudes, 
son de gran interés para mejorar nuestro entendimiento de ésta y porque los procesos originados en el espacio interplanetario dejan su huella ahí. La ionósfera ha sido sondeada con diferentes técnicas de radio, desde observaciones geodésicas (GPS), medidas de radar, hasta el análisis de propagación de ondas de muy baja frecuencia (VLF). Las observaciones simultáneas e integradas han permitido estudiar la ionósfera desde la región $\mathrm{F}$ hasta la base de la capa $\mathrm{D}$, así como los procesos de acoplamiento de la magnetósfera hasta la atmósfera neutra. El estudio de la conectividad Antártida-Sudamérica es importante para entender y caracterizar cómo las variaciones atmosféricas polares pueden afectar las bajas latitudes, y en qué contexto son esenciales las redes de intrumentos. El presente artículo presenta las técnicas de radiometría que han sido usadas para sondear la ionósfera en la estación antártica brasileña Comandante Ferraz y sobre territorio sudamericano, así como las características de la intrumentación y a cuáles redes ésta se encuentra integrada. Presentamos también algunos resultados de investigación obtenidos recientemente de estos sondeos.

Palabras clave: Ionósfera; radio-sondeo; Antártida; América del Sur.

\section{INTRODUCTION}

The earth's upper atmosphere is basically controlled by solar forcing, which is responsible by formation of the ionosphere, the atmospheric plasma layer between about $60 \mathrm{~km}$ and $1000 \mathrm{~km}$ of height. The ionosphere is formed by solar radiation, but when Sun becomes active and solar flares occur, there is an increase of the ionizing radiation that changes its electron density profile. The ionosphere is also disturbed by the solar and the galactic cosmic rays, which energetic particles precipitate deeper in the atmosphere at higher latitudes. The lower ionosphere is essentially maintained by the solar Lyman-alpha radiation (Nicolet \& Aikin 1960) that controls the ionization processes, and also by atmospheric chemistry and dynamics. So, when the Sun becomes active and/or the lower-lying layers of atmosphere are under strong winds the lower ionosphere could present a complex and extremely variable behavior. In addition to these difficulties to characterize the ionosphere behavior, it is not accessible to in situ measurements, being only accessible by rockets or by ground-based soundings, which results in the ionospheric region less understood. So the lower ionosphere is under the solar-driven and dynamical atmosphere competitive processes, which means, when the Sun is active or during geomagnetic storms the solar-driven processes are dominant, whereas at quiet periods the dynamical atmospheric processes are dominant (Lastovicka 2009). The effects of the atmospheric processes in the lower ionosphere have been observed especially during the wintertime
(Lastovicka 2006), and have been attributed to atmospheric waves, mostly of tropospheric origin, namely the gravity and planetary waves and tides.

To improve our understanding of the external forcing of the ionosphere, simultaneous and integrated observations are desirable to study its coupling process with the magnetosphere, as well with the lower-lying atmospheric layers. And, the study at higher latitudes is especially important because there the signatures of the interplanetary space processes are footprinted. In addition, the probing of ionosphere with instrument networks in Antarctica and South-America will improve our understanding of the connectivity between high and lower latitudes phenomena, which can be crucial to define their role in the climate changes

Here we describe the current capabilities for probing the ionosphere at Comandante Ferraz Brazilian Antarctic Station (EACF) and South America, and show some recent advances in ionospheric science.

\section{IONOSPHERIC RADIO SOUNDINGS}

The ionosphere is very complex and dynamic due the great variety of external-driven processes. So, the simultaneous observations of the ionosphere with a variety of experimental techniques are desirable to properly characterize its plasma conditions under the external forcing. In this section, there is an overview of the radio sounding techniques have been used at EACF (62.11S, 58.41W) and South America to probe the ionosphere. 


\section{VERY LOW FREQUENCY (VLF) SOUNDING}

VLF radio waves have been used to study the variations in the lower ionosphere, D-region (60 $85 \mathrm{~km})$. This region is maintained by the solar Lymanalpha radiation (Nicolet \& Aikin 1960) during quiet periods, but can be highly disturbed by enhancements of X-ray emission during solar flares (McRae \& Thomson 2004, Raulin et al. 2006, Raulin et al. 2010), as well by electron precipitation events from the radiation belts (Helliwell et al. 1973, Inan et al. 1982, Fernandez et al. 2003, Peter \& Inan 2004, Correia et al. 2007, Correia et al. 2010b). These disturbances produce changes in the electron density of the D-region that affects the conductivity gradient and/ or the reference height, which govern the refractive index (Wait \& Spies 1964). VLF amplitude and phase are sensitive to these parameter changes, so they can be used to probe ionospheric variations.

VLF sounding is performed with signals at frequencies between 1 and $50 \mathrm{kHz}$, propagating over long distances inside the earth-ionosphere waveguide. The VLF measurements at EACF were done from 1986-1995 using a TRACOR receiver to detect phase and amplitude of the signals. From 1995 the VLF amplitude signals have been detected with $20 \mathrm{~ms}$ time resolution using a Stanford MSK receiver (Johnson et al. 1999). And after 2006, the VLF measurements have been done with one Atmospheric Weather Electromagnetic system for Observation, Modeling and Education receiver - AWESOME (Scherrer et al. 2008), which detects the amplitude and phase of the signals with $20 \mathrm{~ms}$ time resolution, as well broad-band data in the $1-50 \mathrm{KHz}$ frequency range.

VLF measurements using an AWESOME receiver have also been done at Itapetinga Radio Observatory in Atibaia/Brazil (23.21S, 46.51W) since 2006. Recently, the VLF soundings were expanded with the operation of the South America VLF Network (SAVNET, Raulin et al. 2009) with receivers located at (diamonds in Figure1a): Piura/Peru (PIU-5.21S, 80.51W), Punta Lobos/Peru (PLO-12.51S, 76.81W), Ica/Peru (ICA-14.07S, 75.73W) and CASLEO/ Argentina (CAS-31.51S, 68.51W) in the South America, Palmas (PAL-10.171S, 49.341W), Santa Maria (SMS-29.721S, 53.721W) and Atibaia (ATI23.12S, 46.55W) in Brazil, and in Antarctica (EACF). The SAVNET detects the amplitude and phase of
VLF signals with 1s time resolution. At EACF and Atibaia are operating two distinct VLF receivers, one AWESOME and another from the SAVNET network.

The VLF transmitter stations tracked are the US Navy communication Stations at Cutler/Maine (NAA at $24 \mathrm{kHz}, 44.651 \mathrm{~N}, 67.31 \mathrm{~W}$ ), Jim Creek/Washington (NLK at $24.8 \mathrm{kHz}, 48.21 \mathrm{~N}, 121.921 \mathrm{~W}$ ), Lualualei/ Hawaii (NPM at $21.4 \mathrm{kHz}, 20.41 \mathrm{~N}, 158.21 \mathrm{~W}$ ), LaMoure/North Dakota (NLM at 25.2kHz, 46.351N, 98.331W) and Aquada/Puerto Rico (NAU at $40.75 \mathrm{kHz}, 18.41 \mathrm{~N}, 67.181 \mathrm{~W}$ ) (triangles in Figure 1a), and also Harold E. Holt/ North West Cape in Australia (NWC at $19.8 \mathrm{kHz}, 21.8 \mathrm{~S}, 114.2 \mathrm{E}$ ), which permits the study of different ionospheric paths, some of them inside the South Atlantic Magnetic Anomaly.

\section{RIOMETERS}

The relative ionospheric opacity meter (riometer) monitors the background cosmic radio noise at high frequencies (usually $20-50 \mathrm{MHz}$ ) received on the ground. This technique is based on the comparison of the received signal with a Quiet Day Curve (QDC) obtained during geomagnetically undisturbed days, which gives the attenuation of the signal and hence the cosmic radio noise absorption (CNA) at the monitored frequency. Most of this absorption occurs in the D-region of the ionosphere where the electronneutral collision frequency is high. The CNA is caused by the increase of electron density produced by the precipitation of electrons, or other physical phenomena, which raises collision frequency and so the wave absorption. The first riometers consisted of a simple dipole antenna that receives cosmic radio noise with a broad beam $\left(>60^{\circ}\right)$, which initial discoveries were documented by Hargreaves (1969). Nowadays narrow beam riometers have been used to probe small-scale features and the development of the imaging riometers (Detrick and Rosenberg, 1990) have allowed 2-D spatial maps of the lower ionosphere to be produced.

At EACF this technique started to be used in 2009 with the installation of 1-channel riometer at $30 \mathrm{MHz}$, and it was expanded with the installation of two 1-channel receivers at $38 \mathrm{MHz}$, one of them for polarization measurements. All riometers are elements of the South America Riometer Network (SARINET - an International Scientific Cooperation 
between Japan, Brazil, Argentine and Chile) that is operating with an array of 11 riometers (1-channel and/or imaging) (Figure 1b) in operation in the South America; five of them in the Brazilian territory. The

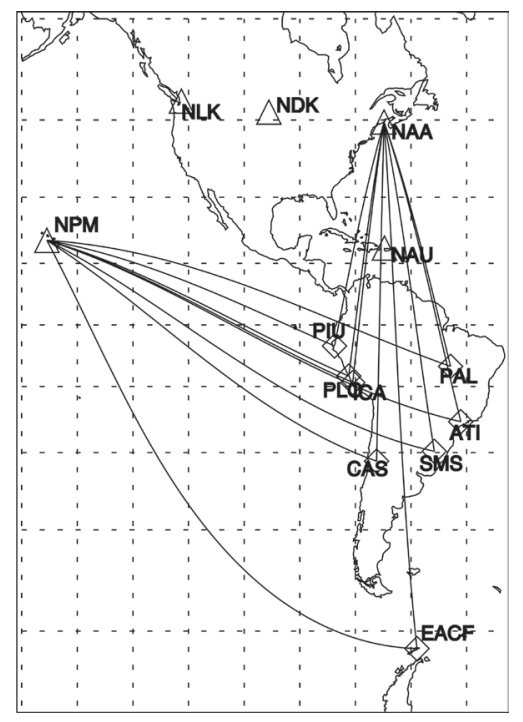

(a) imaging riometer is a set of receivers that use a phased array of antennas to form a number of regularly spaced narrow beams, which measure CNA in various directions and allowed to produce 2-D spatial maps.

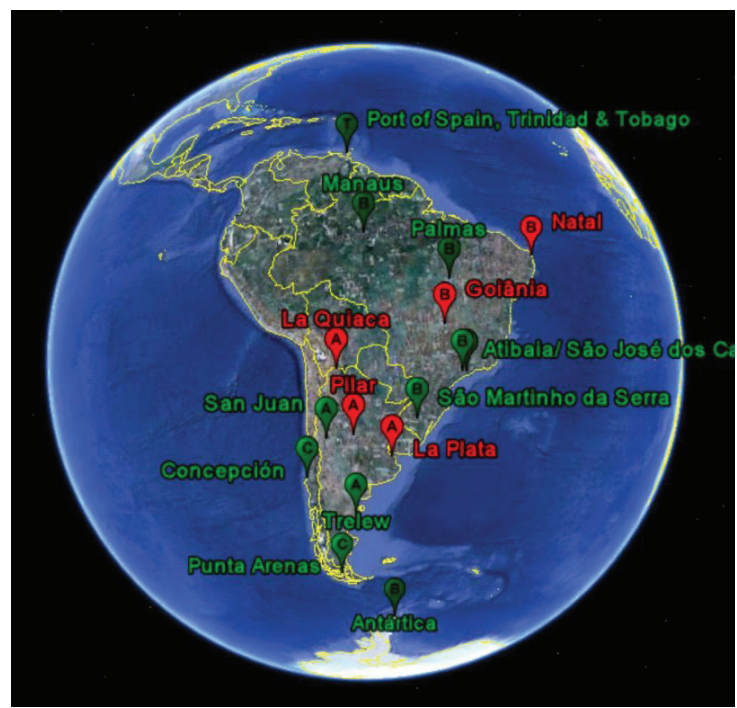

(b)

Figure 1. (a): examples of VLF propagation paths from transmitters NPM and NAA (triangles), to the SAVNET receivers (diamonds) operating in Brazil, Peru, Argentine and at EACF. Figure adapted from Raulin et al. (2010). (b): SARINET riometer stations: 11 in operation (green, light) and 5 in implementation (red,darker).

\section{GLOBAL POSITIONING SYSTEM (GPS) RECEIVERS}

This technique is based on the property that dual frequency radio signals $(\mathrm{L} 1: 1.575 \mathrm{GHz}$ and L2: $1.228 \mathrm{GHz}$ ) propagating through the ionosphere are subjected to a differential phase change due to the dispersive nature of the plasma. As a first-order approximation the differential phase shifts is directly proportional to the Total Electron Content (TEC), which is defined as the line integral of the electron concentration along the path from a satellite to a receiver. The ionosphere has been monitored at EACF since 2004 using a dual frequency Javad GPS receiver with best time resolution of $1 \mathrm{~s}$. The GPS measurements at EACF are complemented with data from the Brazilian GPS network (Rede Brasileira de Monitoramento Contínuo, RBMC) of the Instituto Brasileiro de Geografia e Estatística (IBGE), which nowadays has more than 60 operational receivers covering all regions of the Brazilian territory (http:// www.ibge.gov.br/home/geociencias/geodesia/rbmc/ rbmc inf. php). The GPS network permits to study the latitudinal extension of the ionospheric disturbances, from Antarctica till equatorial region.

\section{VERTICAL IONOSPHERIC SOUNDING - IONOSONDE}

The ionosphere can also be vertically probed by ionosondes that consist of a transmitter of signals at frequencies between 1 and $20 \mathrm{MHz}$, and a receiver to detected the reflected signals. The echoes of the signal reflected by the $\mathrm{F}$ and $\mathrm{E}$ regions of the ionosphere provide a profile of reflection frequency versus virtual height (ionogram), which gives the electron density (directly related to the reflection frequency) profile as a function of actual height (Piggott \& Rawer 1972). The vertical sounding plays a crucial role in understanding the temporal and spatial evolution of the $\mathrm{F}$ and $\mathrm{E}$ regions of the ionosphere, which could help in study of the coupling between lower atmospheric layers (stratosphere and troposphere). At EACF there is a Canadian Advanced Digital 
Ionosonde (CADI, MacDougall 1997). The CADI has been in operation since March 2009, taking 12 ionograms and 24 ionospheric drift measurements per hour.

\section{SOME RECENT RESULTS OF THE IONOSPHERIC SOUNDING}

VLF sounding has been used to study the solar flare impact in the lower ionosphere, the D-region.

The excess of the X-rays radiation produced during the solar flare increases the electron density in this region, which effect is identified as sudden phase anomalies (SPAs) at VLF signals. The analyses of SPAs have shown that the D-region is affected by the 11-year variations of the solar ionizing radiation, and that it is more sensitive during periods of low solar activity, when the ionospheric reference height is about $1 \mathrm{~km}$ higher (McRae \& Thomson 2004, Pacini \& Raulin 2006, Raulin et al. 2006). One recent study of SPAs detected with SAVNET during the last minimum of solar activity (20062009) showed that $100 \%$ of the solar X-ray events with peak flux above $5 \times 10^{-7} \mathrm{~W} / \mathrm{m}^{2}$ in the $0.1-0.8 \mathrm{~nm}$ wavelength range produce a significant SPA, but a weak X-ray event with flux of about $2.7 \times 10^{-7} \mathrm{~W} / \mathrm{m}^{2}$ can be enough to affect the lower ionosphere in $20 \%$ of the cases (Figure 2, Raulin et al. 2010).

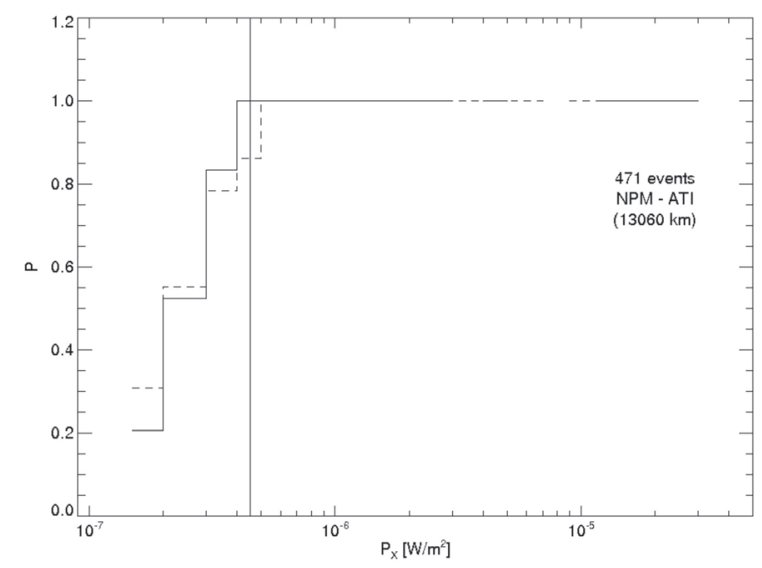

Figure 2. Solar flare probability detection $\mathrm{P}$, as a function of the soft X-ray peak flux Px for the long NPM - ATI VLF propagation path, and for solar zenith angle greater (dashed line) or lower (full line) than 40 degrees. Figure adapted from Raulin et al. (2010)

Long term data analysis of the daytime VLF amplitude has been considered to study the solar forcing in the D-region. Considering the averaged level of the daytime VLF amplitude during the summer season (December-January), when the solar illumination is maximum in the NPM-EACF path, the VLF amplitude from 2004 through 2009 shows a slow decrease of about $-0.63 \mathrm{~dB} /$ year, which accompanies the decrease of the solar Lymanalpha radiation intensity (Figure 3, Correia et al. 2010a) during the decay of the 23rd solar cycle. This behavior shows that the D-region is controlled by solar Lyman-alpha radiation during quiescent periods, which is the main responsible for the formation and the maintenance of this region due the ionization of the nitric oxide (NO) molecules (Nicolet \& Aikin 1960). A similar decrease rate of the VLF amplitude, of about $-0.7 \mathrm{~dB} /$ year, was found during the decay of the $22^{\text {nd }}$ solar cycle by Thomson \& Clilverd (2000), which analysis started in the maximum of that solar cycle. The decrease of the VLF amplitude during the decay of solar activity is explained by the reduction of the photoionization in the D-region due the decrease of the solar Lyman-alpha radiation. So, the long-term VLF soundings can be used as a proxy of Lyman-alpha solar radiation in decadal time scales, because this radiation is not measured continuously by the satellites. A detailed analysis of the association between VLF amplitude and the solar Lyman-alpha radiation is needed to define the minimum sensitivity of this proxy. Figure 3 shows the VLF amplitude has a complex annual behavior, presenting an overall decrease during the wintertime (April-October) when the stratosphere temperature decreases (lower curve in Fig. 3). This behavior is due the solar illumination decrease during the wintertime in the southern hemisphere. In addition, during the wintertime the VLF amplitude also shows strong fluctuations with 16-day period (Correia et al. 2010a), which is typical of planetary waves (Day \& Mitchell 2010). Thus, the results of the long term study show that the lower ionosphere at midlatitudes is affected by competitive processes. The solar-driven processes consist basically of the solar ionizing radiation that dominate in long time scale in close association with 11-year solar cycle and in annual scale with the solar illumination, while during the wintertime the dynamical atmospheric processes dominate. 


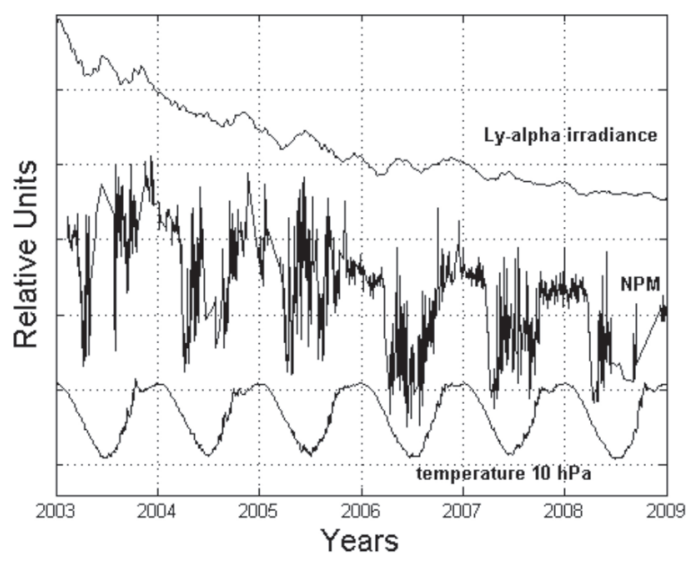

Figure 3. Daytime VLF amplitude of NPM as received at EACF from $1 / 1 / 2003$ to $31 / 12 / 2008$ (NPM trace) compared with 27-day smoothed solar Lyman-alfa radiation (Ly-alpha irradiance trace) and the stratosphere temperature measured at southern midlatitudes (temperature trace). Figure adapted from Correia et al. (2010a).

In addition of the solar ionizing radiation, the ionosphere is also affected by space weather, which consist of many inter-related phenomena that control the lower ionosphere variability at high latitudes, particularly at night. The most important space weather phenomena impacting the lower ionosphere are the geomagnetic storms, which affect substantially both at mid- and high-latitudes, as well solar proton events (SPEs) (e.g. Lastovicka 2009) and relativistic electron precipitation (REP) events (Rodger et al. 2007).

The effects of the geomagnetic storms are more pronounced at high- and mid-latitudes because there the income energetic particles can penetrate deeper in the atmosphere, increasing the electron density of the lower ionosphere. This densification of ionosphere is detected as radio wave absorption, and when is of great intensity, could result in telecommunication blackouts. Bursts of precipitated electrons have been detected as fast variations $(<1 \mathrm{~s})$ in the amplitude and/ or phase of VLF signals, taking about 10- to 30-s to recover the pre-event level. They are attributed to a secondary ionization produced by precipitating electrons with $>50 \mathrm{keV}$ energy (Helliwell et al. 1973) from the radiation belts, which alter the earthionosphere waveguide mode structure, changing the conductivity of the D-region of the ionosphere. The VLF amplitude variations associated with electron precipitating events tend to be negative, as expected from single-mode theory (Inan \& Carpenter 1987). The occurrence of VLF bursts is highly variable and presents a close association with geomagnetic storms, when the energetic electron population in the slot region of the radiation belts increases (Peter et al. 2005).

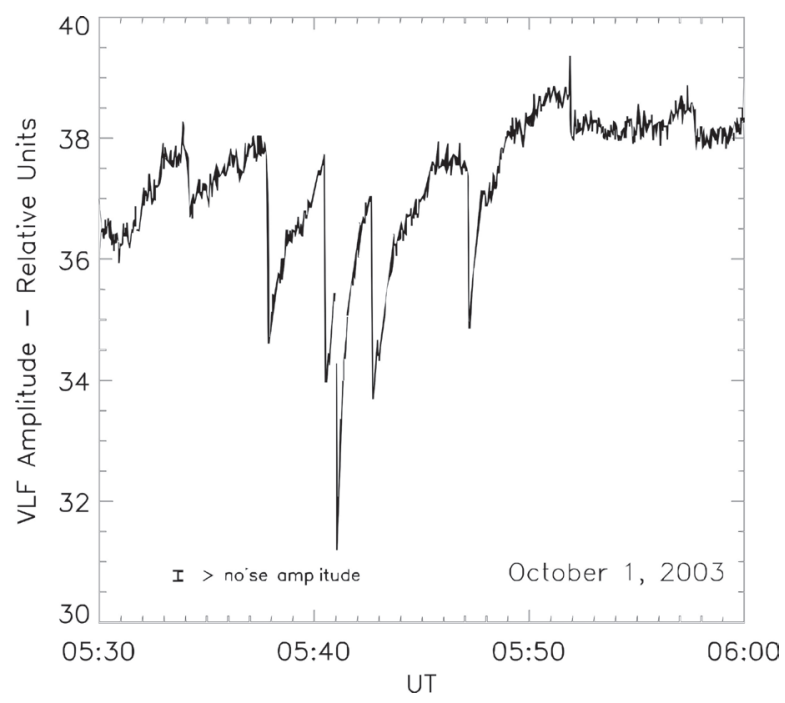

Figure 4. Examples of VLF bursts detected at EACF on October 1st 2003 in the great circle path EACF-NPM. Figure adapted from Correia et al. (2007).

These VLF bursts are produced by electrons from radiation belts that precipitated into the atmosphere due resonant interactions with electromagnetic waves. The electromagnetic waves have been considered to be predominantly the whistler waves generated by lightning, and the associated VLF bursts called lightning - LEP (e.g. Helliwell et al. 1973, Inan et al. 1978, Inan \& Carpenter 1987). But, statistical analysis of these bursts had shown they occur mostly during the equinoxes (Fernandez et al. 2003) in close association with the occurrence of geomagnetic storms (Peter \& Inan 2004, Peter et al. 2005), suggesting a connection with magnetospheric phenomena.

Fast VLF perturbations were also observed during rainstorm type precipitation of relativistic electrons of energies $\mathrm{E}>2 \mathrm{MeV}$ (Rodger et al. 2007), in close association with increases of the relativistic electrons flux in the radiation belts. This suggests that during geomagnetic storms the electron precipitating events are closely related with mechanisms in the inner magnetosphere, where intense whistler-mode chorus waves can be generated during the impact of High Speed Solar Wind Streams - HSSWSs (Summers et al. 2004). So, these bursts might be also produced by the electron resonant interaction with whistler- 
mode chorus waves generated by the anisotropic $10-100 \mathrm{keV}$ electrons injected in the magnetosphere during the impact of HSSWSs (Baker et al. 1998), not only by the whistler-waves generated by lightning. This suggestion is reinforced by the fact they occur more frequently during the main/recovering phase of geomagnetic storms produced by HSSWS (Correia et al. 2007, 2010b).

\section{EXPECTATION OF THE INTEGRATED IONOSPHERIC SOUNDING}

Ionospheric sounding using simultaneous and integrated techniques will improve our understanding of the Sun-Earth interactions. This combined diagnostic approach can provide a more powerful tool for analyzing ionospheric phenomena, and to characterize temporal and spatial the space weather impacts. The use of instrument networks in the South America and Antarctica will improve our understanding of their connectivity, with special interest in the region of the South Atlantic Magnetic Anomaly, where the ionosphere is only possible to be sound from the ground.

Many of these results were obtained in the context of the International Polar Year, inside the activities of the ICESTAR/IHY (Cluster 63) (Alfonsi et al. 2008) and national activities of the Geospace project (CNPq/ PROANTAR). The IPY (2007-2009) effort was an opportunity to bring many international scientific communities together, and in the Brazilian context, increased the collaboration between Universities and Research Institutions to improve the capabilities of understanding our planet and beyond.

ACKNOWLEDGEMENTS: This work was partially sponsored by the Brazilian Antarctic Program (PROANTAR/MMA, CNPq Process $\left.\mathrm{n}^{\circ} .: 52.0186 / 06-0\right)$, SECIRM, INPE and INCT-APA (CNPq Process $\mathrm{n}^{\circ}$. 574018/2008-5, FAPERJ Process n ${ }^{\circ}$. E-26/170.023/2008). EC would like to thank CNPq (Proc: 300710/2006-2) for their partial support. EC thanks the technicians Armando Hadano and José Roberto Chagas from INPE, for the support in Antarctica. I would like to thank the referees for careful reading of the text, and suggestions that improved the paper.

\section{REFERENCES}

ALFONSI, L.; KAVANAGH, A.J.; AMATA, E.; CILLIERS, P.; CORREIA, E.; FREEMAN, M.; KAURISTIE, K.; LIU,
R.; LUNTAMA, J-P.; MITCHELL, C.N. \& ZHEREBTSOV, G.A. 2008. Probing the high latitude ionosphere from groundbased observations: The state of current knowledge and capabilities during IPY (2007-2009). Journal of Atmospheric and Solar-Terrestrial Physics, 70: 2293-2308, doi:10.1016/j. jastp.2008.06.013

BAKER, D.N.; LI, X.; KANEKAL, S.G.; OGILVIE, K.W.; LEPPING, R.P.; BLAKE, J.B.; CALLIS, L.B.; ROSTOKER, G.; SINGER, H.J. \& REEVES, G.D. 1998. A strong CME-related magnetic cloud interaction with the Earth's magnetosphere: ISTP observations of rapid relativistic electron acceleration on May 15, 1997. Geophysical Research Letters, 25: 2975-2978.

CORREIA, E.; FERNANDEZ, J.H. \& RAULIN, J-P. 2007. On the determination of lower ionosphere perturbations detected as fast amplitude variations of VLF signals. Oecologia Brasiliensis, 11(1): 23-28, doi: 10.4257/oeco2007.1101.03

CORREIA, E.; KAUFMANN, P.; RAULIN, J-P.; BERTONI, F. \& GAVILA N, H.R. 2010a. Antarctic long term daytime ionospheric behavior from 2004-2008. Journal of Atmospheric and Solar-Terrestrial Physics. (submitted).

CORREIA, E.; RAULIN, J-P.; FERNANDEZ, J.H.; MAKHMUTOV. V. \& KAUFMANN, P. 2010b. On the signatures of electron precipitation events in the low ionosphere. Journal of Atmospheric and Solar-Terrestrial Physics. (submitted).

DAY, K.A. \& MITCHELL, N.J. 2010. The 16-day wave in the Arctic and Antarctic mesosphere and lower thermosphere. Atmospheric Chemistry and Physics 10: 1461-1472.

DETRICK, D.L. \& ROSENBERG, T.J. 1990. A phased-array radiowave imager for studies of cosmic noise absorption. Radio Science, 25 (4): 325-338.

FERNANDEZ, J.H.; RIZZO PIAZZA, L. \& KAUFMANN, P. 2003. Trimpi occurrence and geomagnetic activity: Analysis of events detected at Comandante Ferraz Brazilian Antarctic Station ( $\mathrm{L}=2.25)$. Journal of Geophysical Research, 108(A1): SIA10-SIA17.

HARGREAVES, J.K. 1969. Auroral Absorption of HF radio waves in the ionosphere: a review of results from the first decade of riometry. Proceedings of the IEEE, 57: 1348-1373.

HELLIWELL, R.A.; KATSUFRAKIS, J.P. \& TRIMPI, M.L. 1973. Whistler-induced amplitude perturbation in VLF propagation. Journal of Geophysical Research, 78: 4679-4688. 
INAN, U.S.; BELL, T.F. \& CHANG, H.C. 1982. Particle precipitation induced by short-duration VLF waves in the magnetosphere. Journal of Geophysical Research, 87: 62436264.

INAN, U.S.; BELL, T.F. \& HELLIWELL, R.A. 1978. Nonlinear pitch angle scattering of energetic electrons by coherent VLF waves in the magnetosphere. Journal of Geophysical Research, 83: 3235-3253.

INAN, U.S. \& CARPENTER, D.L. 1987. Lightning-induced electron precipitation events observed at $\mathrm{L} \sim 2.4$ as phase and amplitude perturbations on subionospheric VLF signals. Journal of Geophysical Research, 92: 3293-3303.

JOHNSON, M.P.; INAN, U.S. \& LAUBEN, D.S. 1999. Subionospheric VLF signatures of oblique (nonducted) whistler-induced precipitation. Geophysical Research Letters, 26: 3569-3572.

LASTOVICKA, J. 2006. Forcing of the ionosphere by waves from below. Journal of Atmospheric and Solar-Terrestrial Physics, 68: 479-497.

LASTOVICKA, J. 2009. Lower ionosphere response to external forcing: A brief review. Advances in Space Research, 43 (1): 1-14.

MACDOUGALL, J.W. 1997. Canadian Advanced Digital Ionosonde Users Manual. University of Western Ontario, Scientific Instrumentation. Ltd. 90p.

MCRAE, W.M. \& THOMSON, N.R. 2004. Solar flare induced ionospheric D-region enhancements from VLF phase and amplitude observations. Journal of Atmospheric and Terrestrial Physics, 66: 77-87.

NICOLET, M. \& AIKIN, A.C. 1960. The Formation of the D-Region of the Ionosphere. Journal of Geophysical Research, 65 (5): 1469-1483.

PACINI, A.A. \& RAULIN, J.-P. 2006. Solar X-ray flares and ionospheric sudden phase anomalies relationship: a solar cycle phase dependence. Journal of Geophysical Research, 111: A09301.

PETER, W.B. \& INAN, U.S. 2004. On the occurrence and spatial extent of electron precipitation induced by oblique nonducted whistler waves. Journal of Geophysical Research, 109: A12215.

PETER, W. B.; CHEVALIER, M.; \& INAN, U. S. 2005. Subionospheric VLF measurements of the effects of geomagnetic storms on the midlatitude D-region. 11th International Ionosphere Effects Symposium A070, 3-5 May 2005: 1-8.
PIGGOTT, W.R. \& RAWER, K. 1972. U.R.S.I. Handbook of Ionogram Interpretation and Reduction, World Data Center A for Solar-Terrestrial Physics. NOAA, Boulder, CO. 90p.

RAULIN, J-P.; ABE PACINI, A.; KAUFMANN, P., CORREIA, E.; APARECIDA, G. \& MARTINEZ, M. 2006. On the detectability of solar X-ray flares using very low frequency sudden phase anomalies. Journal of Atmospheric and Terrestrial Physics, 68: 1029-1035.

RAULIN, J-P.; BERTONI, F.C.P.; GAVILÁN, H.R.; GUEVARADAY, W.; RODRIGUEZ, R.; FERNANDEZ, G.; CORREIA, E.; KAUFMANN, K.; PACINI, A.; STEKEL, T.R.C.; LIMA, W.L.C.; SCHUCH, N.J.; FAGUNDES, P.R. \& HADANO, R. 2010. Solar flare detection sensitivity using the South America VLF Network (SAVNET). Journal of Geophysical Research, 115: A07301, doi:10.1029/2009JA015154

RAULIN, J.-P.; DAVID, P.; HADANO, R.,; SARAIVA, A. C. V.; CORREIA, E. \& KAUFMANN, P. 2009. The South America VLF NETwork (SAVNET). Earth, Moon and Planets, 104: $247-261$.

RODGER, C.J.; CLILVERD, M.A.; NUNN, D.; VERRONEN, P.T.; BORTNIK, J.; TURUNEN, E. 2007. Strom-time, shortlived bursts of relatisvistic electron precipitation detected by subionospheric radio wave propagation. Journal of Geophysical Research, 112: A07301, doi: 10.1029/2007JA012347

SCHERRER, D.; COHEN, M.; HOEKSEMA, T.; INAN, U.; MITCHELL, R. \& SCHERRER, P. 2008. Advances in Space Research, 42: 1777-1785.

SUMMERS, D.; MA, C. Y.; MEREDITH, N.P.; HORNE, R.B.; THORNE, R.M. \& ANDERSON, R.R. 2004. Modeling outerzone relativistic electron response to whistler-mode chorus activity during substorms. Journal of Atmospheric and Solar Terrestrial Physics, 66: 133-146.

THOMPSON, N.R. \& CLILVERD, M.A. 2000. Solar cycle changes in daytime VLF subionospheric attenuation. Journal of Atmospheric and Solar-Terrestrial Physics, 62: 601-608.

WAIT, J.R. \& SPIES, K. 1964. Characteristics of the Earthionosphere waveguide for VLF radio waves. NBS Technical Note, 300. National Bureau Of Standard, Gaithersburg, Md. 100p.

Submetido em 30/08/2010. Aceito em 28/12/2010 